\title{
DEVELOPMENT OF LANGUAGE (Analisis Urgensi Bagi Peserta Didik Perspektif Psikologi Dan Islam)
}

\author{
Achmad Baihaqi \\ Universitas Islam Negeri Sunan Ampel Surabaya \\ Email: abaihaqi853@gmail.com
}

M. Mansyur

STAI Miftahul Ulum Pamekasan

Email: mansyurhurdi@gmail.com

\begin{abstract}
This discussion aims to provide insights in developing language based on psychological and Islamic perspectives. In psychological perspective, the ability to develop children's language at ages 4-11 years (learners at the Play Group level until Elementary School grade 5), they must increase their vocabulary continuously increase, language style changes change, and it is better with fluent communication. Developing language in an Islamic perspective is very important, because basically humans have the potential that was needed from birth. In developing language in students, it is necessary to increase the potential in Him to emerge the soul of faith, faith, and piety for God. In the learning process pay attention to how to choose the teacher, accessing the learning environment and honesty of the teacher in the delivery of material so that in developing the language of students able to make students hope that their God, looking for things that are haqq and inner, find out religion and general by getting used to worship to God Almighty, then learns good norms and is able to socialize well with the community so that students can become human beings (perfect humans) in their lives.
\end{abstract}

Keywords: Development Of Lenguage, Psikologic, and Islam

\section{Pendahuluan}

Mengembangkan bahasa anak didik merupakan salah satu aspek yang sangat penting dalam perkembangan manusia. Di manapun proses pendidikan berlangsung, pendidik membutuhkan pengetahuan kejiwaan anak dalam membantu anak didik agar dapat belajar sebaik mungkin. Oleh karena itu, wajib bagiseorang pendidik untuk memahami sepenuhnya karakteristik dan sifat-sifat anak didik secara psikologis. Kemampuan memahami tingkah laku belajar anak didiknya akan memberi penjelasan bahwa anak sedang dalam keadaan belajar dengan baik atau tidak. Pemahaman yang demikian ini dapat mengukur 
kemampuan belajar dan kemampuan menerima materi pelajaran bagi para anak didiknya.

Memahami dan mengikuti pola mengembangkan anak didik, berarti pendidik dapat memahami pertumbuhan dan mengembangkan belajarnya, serta dapat meningkatkan kemampuan belajar mereka sesuai dengan potensi (fitrah) yang dimiliki masing-masing.

Menurut para psikologi, "psikologi' mendapat tempat di wilayah pendidikan karena berkaitan dengan semua materi pendidikan (educational matter), sehingga kajian dan analisisnya dibutuhkan oleh para pendidik dalam melakukan secara selektif terhadap "metode yang paling tepat" bagi anak didik dengan mempertimbangkan umur serta kelasnya. ${ }^{\text {" }}$

Dalam undang-undang tentang sistem pendidikan nasional dinyatakan bahwa pendidikan anak usia dini adalah suatu upaya pembinaan yang ditujukan kepada anak sejak lahir sampai dengan usia enam tahun yang dilakukan melalui pemberian rangsangan pendidikan untuk membantu pertumbuhan dan mengembangkan jasmani dan rohani agar anak memiliki kesiapan dalam memasuki pendidikan lebih lanjut. ${ }^{2}$

Dilihat dari segi tujuan Islam diturunkan tidak lain adalah untuk menjadi rahmat bagi sekalian alam, tujuan tersebut mengandung implikasi bahwa Islam sebagai agama wahyu mengandung petunjuk dan peraturan yang bersifat menyeluruh, meliputi kehidupan duniawi dan ukhrawi, lahiriyah dan batiniyah, jasmaniah dan rohaniah. ${ }^{3}$

Menurut Abdurrahman An-Nahlawi,pendidikan harus memiliki tujuan yang sama dengan tujuan penciptaan manusia. Konsepsi tentang alam semesta memperjelas tujuan dasar keberadaan manusia di muka bumi ini, yaitu penghambaan, ketundukan kepada Allah, dan kekhalifahannya di muka ini akan menjauhkan manusia dari sikap eksploitasi alam. ${ }^{4}$

\section{Tahapan Mengembangkan Bahasa Pada Anak}

Pertumbuhan dan mengembangkan pada dasarnya adalah 'perubahan menuju ke tahap-tahap yang lebih tinggi dan lebih baik. Pertumbuhan lebih banyak berkenaan dengan aspek-aspek jasmaniah atau fisik, menunjukkan perubahan atau penambahan secara kuantitas, yaitu penambahan dalam ukuran

\footnotetext{
${ }^{1}$ Baqir Sharif al Qarashi, Seni Mendidik Islami: Kiat-Kiat Menciptakan Generasi Unggul, (Jakarta: Pustaka Zahra, 2003), 36.

${ }^{2}$ UU Nomor 20 Tahun 2003 Bab I Pasal 1 Ayat 14.

${ }^{3}$ Bashori Muchsin, dan Abdul Wahid, Pendidikan Islam Kontemporer, (Bandung: Refika Aditama, 2009), 43.

${ }^{4}$ Abdurrahman An-Nahlawi, "Ushul al-Tarbiyah Islamiyah wa Salibiha fi Bait wa al-Madrasati wa Mujtama”, terj., Shihabuddin, Pendidikan Islam Di Rumah, Sekolah, dan Masyarakat, (Jakarta: Gema Insani, 1995).
} 
besar atau tinggi. Sedangkan 'mengembangkan' berkaitan dengan aspek-aspek psikhis atau rohaniah, berkenaan dengan kualitas, yaitu peningkatan dan penyempurnaan fungsi. ${ }^{5}$

Bahasa adalah alat komunikasi yang dapat diartikan sebagai tanda, gerak dan suara untuk menyampaikan isi pikiran kepada orang lain. Taringan menjelaskan bahwa bahasa merupakan alat untuk meningkatkan kemampuan intelektual, serta kematangan emosional dan sosial. ${ }^{6}$

Mengembangkan bahasa anak tidak saja dipengaruhi oleh mengembangkan neurologis tetapi juga oleh mengembangkan biologisnya. Menurut Lenneberg, dikatakan bahwa mengembangkan bahasa anak mengikuti jadwal biologis yang tidak dapat ditawar-tawar. Seorang anak tidak dapat dipaksa atau dipacu untuk dapat mengujarkan sesuatu, bila kemampuan biologisnya belum memungkinkan. Sebaliknya, bila seorang anak secara biologis telah dapat mengerjakan sesuatu, dia tidak akan dapat pula dicegah untuk tidak mengujarkannya. Karena memang ada keterkaitan antara mengembangkan biologi dengan kemampuan berbahasanya. ${ }^{7}$

\section{Mengembangkan Bahasa Pada Peserta Didik Dalam Persfektif Psikologi}

Psikologi mengembangkan merupakan salah satu bidang psikologi yang memfokuskan kajian atau pembahasannya mengenai perubahan tingkah laku dan proses mengembangkan dari masa konsepsi (pra-natal) sampai masa kematian. ${ }^{8}$ Dalam psikologi mengembangkan qur'ani, batasan kematian itu tidak menjadi halangan pengkajian tentang perilaku manusia, hingga pada batas tertentu pasca kehidupanpun manusia masih bisa difahami jalan kehidupannya. ${ }^{9}$

Jean Piaget membagi tingkat mengembangkan kognisi menjadi empat tahap, yaitu: ${ }^{10}$ periode sensorimotor (umur 0-2 tahun), periode praoperasional (umur 2-6 tahun), periode operasional konkret (umur 6-11 tahun), periode operasional formal (umur 11-dewasa).

Dalam teori ini,Jean Piaget menjelaskan bahwa anak usia 0-2 tahun itu baru memiliki kemampuan yang terbatas pada gerak-gerak refleks. Reaksi intelektual hampir seluruhnya karena rangsangan langsung dari alat-alat indra.

${ }^{5}$ Syaiful Sagala, Konsep dan Makna Pembelajaran: Untuk Membantu Memecabkan Problematika Belajar dan Mengajar (Bandung: CV Alfabeta, 2003), 94.

${ }^{6}$ Henry Guntur Taringan, Menyimak sebagai suatu Keterampilan Berbahasa, (Bandung: Angkasa, 1986), 10.

${ }^{7}$ Soenjono Dardjowidjojo, Echa: Kisah Pemerolehan Bahasa Anak Indonesia, Jakarta: Gramedia Widiasarana Indonesia, 2000), 60.

${ }^{8}$ Syamsul Yusuf, Psikologi Perkembangan Anak \& Remaja, (Bandung: PT. Remaja Rosdakarya, 2014), 3.

${ }^{9}$ Atiqullah, Dasar-Dasar Psikologi Agama, (Pamekasan: stainpress, 2006), i-ii.

${ }^{10}$ Syamsu Yusuf, Psikologi Perkembangan Anak \& Remaja (Bandung: PT Remaja Rosdakarya, 2004), 3. 
Punya kebiasaan memukul-mukul dan bermain-main dengan permainannya. Mulai dapat menyebutkan nama-nama objek tertentu. Anak usia 2-6 tahun memiliki mengembangkan bahasa yang sangat pesat. Anak mulai menggunakan symbol-simbol untuk merepresentasi dunia (lingkungan) secara kognitif. Simbol-simbol itu berupa kata-kata, bilangan yang dapat menggantikan objek, peristiwa dan kegiatan (tingkah laku yang tampak). Peranan intuisi dalam memutuskan sesuatu masih besar, menyimpulkan hanya berdasarkan sebagian kecil yang diketahui. Analisis rasional belum berjalan. Anak usia 6-11 tahun sudah bisa berpikir logis, sistematis, dan memecahkan masalah yang bersifat konkret. Mereka sudah mampu mengerjakan penambahan, pengurangan, perkalian dan pembagian. Dan anak pada usia 11 tahun - dewasa merupakan operasi mental tingkat tinggi. Mereka sudah mampu berpikir logis terhadap masalah baik yang konkret maupun yang abstrak dan dapat membentuk ide-ide dan masa depan secara realistis.

Sedangkan menurut Syamsul Yusuf LN bila dilihat dari mengembangkan umur kronologis yang dikaitkan dengan mengembangkan kemampuan berbahasa individu, tahapan mengembangkan bahasa dapat dibedakan ke dalam tahap berikut: ${ }^{11}$ tahap pralinguistik atau meraba $(0,3-1,0$ tahun), tahap holofrastik atau kalimat satu kata (1,0-1,8 tahun), tahap kalimat dua kata (1,6-2,0 tahun), tahap pengembangan tata bahasa awal (2,0-5,0 tahun), tahap pengembangan tata bahasa lanjutan (5,0-10,0 tahun), dan terakhir tahap kompetensi lengkap (11,0 tahun - dewasa).

Dalam teori ini, Syamsul Yusuf LN mengemukakan bahwa anak usia 0,3-1,0 tahun baru memiliki kemampuan mengeluarkan bunyi ujaran dalam bentuk ocehan yang mempunyai fungsi komunikasi. Anak yang berusia 1,0-1,8 tahun anak mulai mengucapkan kata-kata. Satu kata yang diucapkan oleh anakanak harus dipandang sebagai satu kalimat penuh, yang mencakup aspek intelektual ataupun emosional sebagai cara untuk menyatakan mau tidaknya terhadap sesuatu. Anak usia 1,6-2,0 tahun anak mulai memiliki banyak kemungkinan untuk menyatakan kemauannya dan berkomunikasi dengan menggunakan kalimat sederhana yang disebut dengan istilah "kalimat dua kata" yang dirangkai secara tepat, contohnya "bapak makan". Anak usia 2,0-5,0 tahun anak mulai mengembangkan tata bahasa, panjang kalimat yang diucapkan mulai bertambah ucapan-ucapan yang dihasilkan semakin kompleks, dan mulai munggunakan kata jamak. Anak usia 5,0-10 tahun anak semakin mampu mengembangkan struktuk tata bahasa yang lebih kompleks lagi serta mampu melibatkan gabungan kalimat sederhana dengan komplemenetasi, relativasi, dan konjungsi. Dan pada tahap akhir, anak usia 11 tahun-dewasa anak memiliki perbendaharaan kata yang terus meningkat, gaya bahasa mengalami perubahan,

${ }^{11}$ Syamsul Yusuf, Psikologi Perkembangan Anak \& Remaja, (Bandung: PT. Remaja Rosdakarya, 2014), 119. 
dan ia semakin lancar serta fasih dalam berkomunikasi. Keterampilan dan performasi bahasa terus berkembang ke arah tercapainya kompetensi berbahasa secara lengkap sebagai perwujudan dari kompetensi komunikasi.

Dari kedua teori diatas, ternyata peserta didik memiliki keberagaman dalam penguasaan mengembangkan bahasa. Hal itu dikarenakan peserta didik dipengaruhi oleh usia peserta didik itu sendiri dan kondisi di lingkungan tempat tinggalnya. Terkadang mereka mengalami kesulitan dalam mengembangkan bahasa, namun dengan adanya bimbingan secara terus-menerus dari orang tua di rumah dan guru di sekolah, mereka akan mengalami perubahan dalam segi penguasaan bahasa.

Setelah peserta didik mampu mengembangkan bahasa dalam kehidupannya, maka menurut penulis mengembangkan bahasa pada peserta didik sangat penting karena bahasa mampu membuat daya nalar peserta didik berkembang dalam menyelesaikan masalah-masalah yang sedang dihadapi oleh peserta didik. Baik dari keterampilan dan performasi bahasa yang terus berkembang ke arah tercapainya kompetensi berbahasa secara lengkap sebagai perwujudan dari kompetensi komunikasi peserta didik yang kalau kita lihat hal itu senada dengan kedua teori di atas.

Dari penjelasan ahli psikologi diatas, maka bisa penulis menyimpulkan bahwa anak pada usia 4-11 tahun mereka memiliki perbendaharaan kata yang terus meningkat, gaya bahasa mengalami perubahan, dan ia semakin lancar serta fasih dalam berkomunikasi.dan ketika mereka berusia dewasa mereka sudah mampu berpikir logis terhadap masalah baik yang konkret maupun yang abstrak dan dapat membentuk ide-ide dan masa depan secara realistis.

\section{Mengembangkan Bahasa Pada Peserta Didik Dalam Persfektif Islam}

Manusia digambarkan oleh Ibnu Tufail dengan kelahiran tokoh Hayy ibn Yaqzhan ${ }^{12}$ dalam dua versi: pertama, Hayy terlahir seperti kebanyakan manusia lainnya, yakni dilahirkan oleh seorang ibu yang secara kebetulan adalah saudara kandung dari seorang raja di kepulauan India. Ayah Hayy bernama Yaqzhan, yang sebenarnya masih kerabat dekat dengan ibunya. Ibu Hayy menikah dengan Yaqzhan secara sembunyi-sembunyi karena ditentang oleh saudara kandungnya, sang raja. Ketika ibunya melahirkan, sang bayi yang kemudian diberi nama Hayy ibn Yaqzhan diletakkan di dalam sebuah peti dan dilempar ke laut, dengan

\footnotetext{
${ }^{12}$ Hayy, yang memiliki arti hidup, adalah simbol dari sesuatu yang tidak pernah mati. Akal adalah sumber dari segala yang ada dan juga sumber pengetahuan sehingga akal adalah juga sumber kehidupan. Ibnu Tufail menampilkan sosok Hayy sebagai anak Yaqzhan. Kata Yaqzhan sendiri berarti sadar. Yaqzhan merupakan personifikasi dari Tuhan, dzat yang tidak pernah lalai dan lengah. Oleh karena itu, Hayy ibn Yaqzhan merupakan perwujudan dari sosok manusia yang dengan akalnya senantiasa berpikir, mengamati dan meneliti untuk memperoleh kebenaran sejati. Lihat lebih lanjut pada sy-Syaikh Kamil MuhammadUwaidah, Ibn Tufail: Failasuf al Islam fi al-'Ashr al-Wasith. hlm. 56-47.
} 
tujuan agar tidak diketahui sang raja karena takut akan ancaman dan siksaannya. Peti yang berisi sang jabang bayi Hayy ibn Yaqzhan itu akhirnya terdampar di sebuah pulau seberang bernama al-waqwaq. Secara kebetulan, datanglah seekor rusa yang sedang mencari anaknya yang juga hilang. Ketika sang rusa mendengar tangis sang bayidan mengira adalah anaknya yang hilang, ia pun kemudian memungut bayi tersebut dan mengasuhnya hingga besar. ${ }^{13}$

Versi kedua, Hayy terlahir dengan sendirinya melalui proses pertumbuhan alam, yang berasal dari segumpal tanah meragi (ikbtimar ath-thinah) di perut bumi di pulau al-waqwaq. Tabah yang bergelembung itu terdiri dari dua bagian yang dipisahkan oleh oleh selaput yang sangat tipis dan berisi sebuah zat udara yang sangat halus, sebagai tempat bersemayamnya ruh dari Tuhan. Dari situlah tercipta sebuah embrio (janin) yang mengalami perkembangan dan berevolusi menjadi seorang bayi yang secara spontan menangis karena merasa lapar. Dalam keadaan seperti itu, tiba-tiba datanglah seekor rusa yang sedang mencari anaknya yang juga hilang. Rusa tersebut kemudian memungut, menyusui, dan mengasuh bayi tersebut hingga besar. ${ }^{14}$

Namun, dari kedua teori kelahiran Hayy ibn Yaqzhan, Ibnu Tufail nampaknya lebih cenderung pada teori kedua, yang pada prinsipnya lebih merupakan eklektisasi teori ilmiah (al-tawallud al-dzati) dengan pandangan Ibnu Sina, yang didasarkan pada teori emanasi (nazariyyat al-faydl), yaitu kelahiran Hayy ibn Yaqzhan dari peragian tanah (ikhtimar al-thin), sehingga mempunyai unsurunsur yang memungkinkannya berproses menjadi sebuah materi, yang siap menerima bentuk dari akal aktif; maka tanah telah berbentuk embrio itu menjadi hidup dan terus berproses secara alami pula, sehingga menjadi bayi secara utuh, baik jasadnya, jiwanya, dan akalnya. ${ }^{15}$

Hayy sebagai manusia yang tumbuh secara alami (naturally), tanpa keluarga, masyarakat, bahasa, budaya, agama, maupun dinamika sosial lainnya. Hayy dengan keingintahuannya yang besar diiringi perkembangan psikis yang memacu kesadaran moral, hingga Hayy mengetahui apa itu malu, iri hati, sombong, cemburu, dan perasaan emosi lainnya.

Maka manusia menurut Ibnu Tufail sebenarnya terdiri dari dua aspek yaitu materi dan imateri. Aspek material senantiasa bersifat jasmani yang cenderung punah, seperti halnya air yang kadang menguap dan berubah menjadi awan dan awan menjadi air. Sedangkan aspek immaterial adalah jiwanya yang merupakan hakekat manusia yang mempunyai tabiat abadi dan kekal sehingga tiada dihinggapi oleh sifat-sifat jasmani sedikitpun. Jiwa inilah yang menurut Ibnu Tufail yang mampu mengetahui yang wajib ada (necessary being), karena

\footnotetext{
${ }^{13}$ Abu Muhammad Iqbal, Pemikiran Pendidikan Islam, (Yogyakarta: Pustaka Pelajar, 2015), 193 194.

${ }^{14} \mathrm{Ibid}, 194$.

${ }^{15}$ Abu Muhammad Iqbal, Pemikiran Pendidikan Islam, (Yogyakarta: Pustaka Pelajar, 2015), 194.
} 
eksistensinya bersumber dari yang wajib ada dan teremanasi dari-Nya. Untuk itu setelah jasad menteri manusia rusak sebab kematian, jiwa senantiasa kekal, yang kesempurnaan dan kebahagiaannya terletak pada musyahadah yang wajib ada secara terus- menerus.

Melalui potensi pengembangan bahasa yang dimilikinya, manusia akan terdorong untuk berfikir dan berbudaya. Agar manusia dapat berfikir kreatif dan berbudaya sangat membutuhkan pertolongan pendidikan dalam arti yang seluasluasnya. ${ }^{16}$ Pentingnya usaha pendidikan dalam rangka pengembangan potensi manusia sejalan dengan apa yang termaktub dalam Al-Qur'an. ${ }^{17}$

Dalam etimologi Islam, potensi dikenal dengan istilah fitrah. Fitrah berasal dari bahasa Arab, yaitu fithrah jamaknya fithar, yang diartikan sebagai perangai, tabi'at, kejadian, asli, agama, ciptaan. Menurut M. Quraish Shihab, istilah fitrah diambil dari akar kata al-fithr yang berarti belahan. ${ }^{18}$ Fitrah juga berarti ciptaan, sifat tertentu yang mana setiap yang maujud disifati dengannya pada awal masa penciptaannya, sifat pembawaan manusia (yang ada sejak lahir), agama, as-sunnah. ${ }^{19}$

Berpijak pada definisi di atas, maka penulis menyimpulkan bahwa potensi adalah sesuatu atau kemampuan dasar manusia yang telah ada dalam dirinya yang siap untuk direalisasikan menjadi kekuatan dan dimanfaatkan secara nyata dalam kehidupan manusia di dunia ini sesuai dengan tujuan penciptaan manusia oleh Allah SWTT.

Syekh Ja'far bin Hasan al-Barzanji yang menulis sebuah karya sastra Kitab Al-Barzanji ini serat dengan nilai pendidikan akhlak. Nilai-nilai pendidikan akhak tersebut diantaranya adalah: pemilihan guru dan lingkungan bagi peserta didik, dan kejujuran dalam penyampaian.

Wan Daud menyatakan bahwa peranan guru dianggap sangat penting, peserta didik disarankan untuk tidak tergesa-gesa belajar kepada sembarang guru, sebaiknya peserta didik harus meluangkan waktu untuk mencari siapakah guru terbaik dalam bidang yang ia gemari. ${ }^{20}$

Selanjutnya Dalyono menyatakan bahwa lingkungan sebenarnya mencakup segala material dan stimulus di dalam dan di luar diri individu, baik yang bersifat fisiologis, psikologis maupun sosial kultural. ${ }^{21}$ Sedangkan menurut Baharudin juga berpendapat bahwa perkembangan manusia menurut alQur'an $^{22}$ adalah manusia sejak lahirnya telah memiliki potensi. Untuk

\footnotetext{
${ }^{16}$ Abuddin Nata, Perspektif Islam tentang Strategi Pembelajaran, (Jakarta: Kencana, 2011), 43.

${ }^{17}$ Q.S. 13:11.

${ }^{18}$ Heri Gunawan, Pendidikan Karakter, (Bandung: Alfabeta, 2012), 41.

${ }^{19}$ Muhaimin, dkk. Paradigma Pendidikan Islam, (Bandung: Remaja Rosdakarya, 2012), 16.

${ }^{20}$ Wan Mohd Wan Daud, Filsafat dan Praktik Pendidikan Islam Syed M. Naquib Al-Attas, Cetakan Pertama, (Bandung: Mizan Media Utama, 2003), 260.

${ }^{21}$ Dalyono, Psikologi Pendidikan, Cet. 4 (Jakarta: PT. Reneka Cipta, 2007), 129-130.

${ }^{22}$ Q.S. $30: 30$ dan Q.S. $16: 78$.
} 
mengaktualkan potensi itu, maka diperlukan lingkungan yang kondusif dalam rangka memberikan kesempatan kepada potensi untuk menjadi aktual. Jadi perkembangan manusia sangat dipengaruhi oleh pembawaan dan lingkungan. ${ }^{23}$

Sementara menurut Mujiono, dkk. merumuskan bahwa keluarga merupakan unit terkecil dalam masyarakat yang dapat dijadikan anak tangga pertama untuk mencapai kebahagiaan hidup baik di dunia maupun di akhirat. Sebuah keluarga jika dikelola dengan baik berdasarkan tuntunan syar’i akan dapat menempatkan anggota keluaarga tersebut pada posisi terhormat dalam masyarakat, serta dapat mendatangkan perasaan sakinah, ketentraman, dan kedamaian bagi seluruh anggota keluarga. ${ }^{24}$

Aspek nilai kejujuran dalam penyampaian dalam kitab al-Barzanji pada bab VII-VIII dijelaskan dengan penceritaan seorang pendeta Kristen bernama Bahira tentang tanda-tanda kenabian Rasulullah SAW. Kedalaman nilai esensi pendidikan Islam seyogyanya menjadi acuan dari para pendidik. Uraian tentang definisi pendidikan Islam di atas, penulis dapat menggaris bawahi bahwa untuk menyampaikan suatu pengetahuan dengan segala aspek nilai diperlukan kedalaman ilmu dan juga kejujuran fikiran dan hati. ${ }^{25}$

Penjelasan dalam buku al-Barzanji di atas itu hampir sama dengan pendapat Abdurrahman An-Nahlawi yang menyatakan bahwa pendidikan harus memiliki tujuan yang sama dengan tujuan penciptaan manusia. Konsepsi tentang alam semesta memperjelas tujuan dasar keberadaan manusia di muka bumi ini, yaitu penghambaan, ketundukan kepada Allah, dan kekhalifahannya di muka ini akan menjauhkan manusia dari sikap eksploitasi alam. ${ }^{26}$ Yang ada hanya sikap memakmurkan alam semesta melalui perwujudan ketaatan pada syariat Allah. Al-Qur'an pun telah menegaskan tujuan penciptaan manusia ini melalui firman Allah dalam Al-Qur'an. ${ }^{27}$

Jika melihat dari beberapa teori di atas terdapat perbedaan antara dua teori yang dikemukakan oleh Ibnu Tufail. Namun Ibnu Tufail lebih cenderung ke teori yang kedua karena pada prinsipnya dianggap lebih eklektisasi teori ilmiah. Teori tersebut dikuatkan dengan adanya teori Syekh Ja'far al-Barzanji dalam Kitab al-Barzanji dan pendapat Abdurrahman An-Nahlawi. Hal itu juga senada dengan penjelasan Allah di dalam al-Qur'an.

Jadi, Peserta didik pada dasarnya memiliki potensi dan potensi itu akan mengalami perubahan dari proses mengembangkan bahasa anak. Bila ditinjau

\footnotetext{
${ }^{23} \mathrm{Abu}$ Muhammad Iqbal, Pemikiran Pendidikan Islam, (Yogyakarta: Pustaka Pelajar, 2015), 445.

${ }^{24}$ Imam Mujiono, dkk., Ibadab dan Akblak dalam Islam, Cet. 2(Yogyakarta: UII Press Indonesia, 2002),109.

${ }^{25}$ Abu Muhammad Iqbal, Pemikiran Pendidikan Islam, (Yogyakarta: Pustaka Pelajar, 2015), 447.

${ }^{26}$ Abdurrahman An-Nahlawi, "Ushul al-Tarbiyah Islamiyah wa Salibiha fi Bait wa al-Madrasati wa Mujtama”, terj., Shihabuddin, Pendidikan Islam Di Rumah, Sekolah, dan Masyarakat, (Jakarta: Gema Insani, 1995).

${ }^{27}$ Q.S. 51: 56.
} 
dari perspektif Islam, maka akan terlihat mulai dari bahasa yang telah dikuasai oleh peserta didik itu mampu mengenalkan hal-hal yang mungkin tidak bisa dirasa oleh panca indranya, seperti cara mereka mengenal Tuhan, mengenal nama-nama dan sifat-sifat Tuhan, pengetahuan akan ilmu-ilmu keIslaman, dan lain sebagainya.

Setelah mereka mampu mengembangkan bahasa sampai mengantarkan peserta didik bisa mengenal akan hal tersebut, maka akan muncul pada diri peserta didik jiwa keyakinan, keimanan, dan ketakwaan kepada Tuhan. Sehingga mampu mempengaruhi sikap dan cara berpikir peserta didik untuk selalu membiasakan diri beribadah kepada Tuhan Yang Maha Esa dan bersosialisasi dengan baik terhadap sesama manusia.

Apabila melihat pengaruh yang ditimbulkan oleh hal di atas, maka menurut penulis mengembangkan bahasa dalam perspektif Islam sangat penting, karena pada dasarnya setiap manusia sudah memiliki potensi yang dibawa sejak lahir. Yang mana potensi tersebut dapat dikembangkan apabila peserta didik dalam proses belajarnya memperhatian cara bagaimana ia dalam memilih guru, kondisi lingkungan temapt ia belajar dan kejujuran guru dalam penyampaian materi sehingga proses dalam mengembangkan bahasa peserta didi mampumenjadikan peserta didik itu mengenal Tuhannya, membedakan sesuatu hal yang haqq dan bathil, menguasai ilmu pengetahuan agama dan umum, mengetahui norma-norma yang baik dan mampu bersosialisasi dengan masyarakat dengan baik sehingga peserta didik itu bisa menjadi insan kamil (manusia sempurna) dalam kehidupannya.

\section{Kesimpulan}

Pemahaman tentang psikologi memberikan wawasan terhadap konsep pendidikan. Wawasan itu sebagian besar berpengaruh terhadap bidang kurikulum, sebab materi pelajaran dan proses pembelajaran, harus sejalan dengan perkembangan anak didik, khususnya mengembangkan berkomunikasi dan bahasa anak.

Dalam perspektif psikologi, mengembangkan bahasa anak pada usia 411 tahun (peserta didik tingkat Play Group sampai Sekolah Dasar kelas 5), mereka sudah memiliki perbendaharaan kata yang terus meningkat, gaya bahasa mengalami perubahan, dan ia semakin lancar serta fasih dalam berkomunikasi.dan ketika mereka berusia 12 tahun - dewasa (Peserta didik sekolah Dasar kelas 6 sampai dewasa), mereka sudah mampu berpikir logis terhadap masalah baik yang konkret maupun yang abstrak dan dapat membentuk ide-ide dan masa depan secara realistis.

Menurut penulis mengembangkan bahasa pada peserta didik sangat penting karena pada dasarnya setiap manusia sudah memiliki potensi salah satunya dalam mengembangkan bahasa yang mampu membuat daya nalar 
peserta didik berkembang dalam menyelesaikan masalah-masalah yang sedang dihadapi oleh peserta didik.

Menurut penulis mengembangkan bahasa dalam perspektif Islamsangat penting, karena mengembangkan potensi bahasa pada peserta didik sangat dibutuhkan olehnya untuk meningkatkan potensi dalam dirinya sehingga akan munculjiwa keyakinan, keimanan, dan ketakwaan kepada Tuhan. Dan dalam proses belajarnya memperhatian cara bagaimana ia dalam memilih guru, kondisi lingkungan temapt ia belajar dan kejujuran guru dalam penyampaian materi sehingga proses dalam mengembangkan bahasa peserta didik mampumenjadikan peserta didik itu mengenal Tuhannya, membedakan sesuatu hal yang haqq dan bathil, menguasai ilmu pengetahuan agama dan umum dengan membiasakan diri beribadah kepada Tuhan Yang maha Esa, kemudian mengetahui norma-norma yang baik dan mampu bersosialisasi dengan masyarakat dengan baik sehingga peserta didik itu bisa menjadi insan kamil (manusia sempurna) dalam kehidupannya.

\section{Daftar Pustaka}

Al Qarashi,Baqir Sharif.Seni Mendidik Islami: Kiat-Kiat Menciptakan Generasi Unggul, Jakarta: Pustaka Zahra, 2003.

An-Nahlawi,Abdurrahman. "Ushul al-Tarbiyah Islamiyah wa Salibiha fi Bait wa al-Madrasati wa Mujtama", terj., Shihabuddin, Pendidikan Islam Di Rumah, Sekolah, dan Masyarakat, Jakarta: Gema Insani, 1995.

Atiqullah, Dasar-Dasar Psikologi Agama, Pamekasan: stainpress, 2006.

Dardjowidjojo,Soenjono.Echa: Kisah Pemerolehan Bahasa Anak Indonesia, Jakarta: Gramedia Widiasarana Indonesia, 2000.

Dalyono, Psikologi Pendidikan, Cet. 4 Jakarta: PT. Reneka Cipta, 2007.

Gunawan,Heri.Pendidikan Karakter, Bandung: Alfabeta, 2012.

Iqbal, Abu Muhammad.Pemikiran Pendidikan Islam, Yogyakarta: Pustaka Pelajar, 2015.

Muchsin,Bashori. dan Abdul Wahid, Pendidikan Islam Kontemporer, Bandung: Refika Aditama, 2009.

Muhaimin, dkk. Paradigma Pendidikan Islam, Bandung: Remaja Rosdakarya, 2012.

Mujiono, Imam. dkk., Ibadah dan Akblak dalam Islam, Cet. 2 Yogyakarta: UII Press Indonesia, 2002.

Nata,Abuddin.Perspektif Islam tentang Strategi Pembelajaran, Jakarta: Kencana, 2011.

Sagala,Syaiful.Konsep dan Makna Pembelajaran: Untuk Membantu Memecabkan Problematika Belajar dan Mengajar, Bandung: CV Alfabeta, 2003.

Taringan,Henry Guntur.Menyimak sebagai suatu Keterampilan Berbahasa, Bandung: Angkasa, 1986. 
UU Nomor 20 Tahun 2003 Bab I Pasal 1 Ayat 14.

Wan Daud, Wan Mohd.Filsafat dan Praktik Pendidikan Islam Syed M. Naquib AlAttas, Cetakan Pertama, Bandung: Mizan Media Utama, 2003.

Yusuf,Syamsul.Psikologi Mengembangkan Anak \& Remaja, Bandung: PT. Remaja Rosdakarya, 2014. 